\title{
Synthesis and study the analgesic and anti-inflammatory effects of rigid benzofurane 3, 4 dihydroxy chalcon $(\mathrm{DHC})$ in mice
}

\author{
Mahmoud Reza Heidari ${ }^{i^{*}}$, Mohammad Heidari ${ }^{1}$, Alireza Foroumadi ${ }^{2}$, Ali Asadipour ${ }^{3}$, Hojat Noroozi ${ }^{1}$ \\ From $1^{\text {st }}$ International Congress on Neurobiology and Clinical Psychopharmacology and European \\ Psychiatric Association Conference on Treatment Guidance \\ Thessaloniki, Greece. 19-22 November 2009
}

\section{Background}

According to bibliography on the structure activity relationship, it seems that the rigid Benzofuran dihydroxy chalcon (DHC) may be more effective on pain and inflammation. In this study the Rigid benzofuran DHC were synthesized and the analgesic and anti-inflammatory effect was evaluated.

\section{Materials and methods}

In this study the rigid benzofuran DHC were synthesized and the analgesic and anti- inflammatory effect of different doses, $12.5,25$ and $50 \mathrm{mg} / \mathrm{kg}$, was evaluated by formalin hot plate and caregeenan tests, in group of 7 mice.

\section{Results}

The resulta showed that 3,4-DHC with dose of $25 \mathrm{mg} / \mathrm{kg}$ induced significant antinociception and anti-inflammation compared with control group. In additon the effect of DHC was higher in the chronic phase of formalin test, therefore it seems that DHC has better anti-inflammatory effect rather than analgesic effect. The dose of $25 \mathrm{mg} / \mathrm{kg}$ of DHC induces significant analgesia in hot plate test and antiu-inflammatory effect in carageenan test too. The doses of 25 and $50 \mathrm{mg} / \mathrm{kg}$, induced lethargy in mice.

\section{Conclusions}

The result showed that with modification of structure of the DHC, this derivative has potential for more studies as a lead compound.

'Department of Toxicology and Pharmacology, Faculty of Pharmacy, Pharmaceutics, Neuroscience and Physiology Research Centers, Kerman University of Medical Sciences, Kerman, Iran

\section{Author details}

${ }^{1}$ Department of Toxicology and Pharmacology, Faculty of Pharmacy, Pharmaceutics, Neuroscience and Physiology Research Centers, Kerman University of Medical Sciences, Kerman, Iran. ${ }^{2}$ Department of Medicinal Chemistry, Faculty of Pharmacy, Pharmaceutics Research Centers, Tehran University of Medical Sciences, Tehran, Iran. ${ }^{3}$ Department of Medicinal Chemistry, Faculty of Pharmacy, Pharmaceutics Research Centers, Kerman University of Medical Sciences, Kerman, Iran.

Published: 22 April 2010

\section{References}

1. Hsieh HK, Lee TH, Wang JP, et al: synthesis and anti - inflammatory effect of chalcones and related compounds. Pharm Res 1998, 15(1):39-46.

2. Sogawa S, Nihro $Y$, Ueda H, et al: 3,4-Dihydroxychalcones as potent 5-lipoxygenase and cyclooxygenase inhibitors. J Med Chem 1993, 36:3904-3909.

doi:10.1186/1744-859X-9-S1-S124

Cite this article as: Heidari et al:: Synthesis and study the analgesic and anti-inflammatory effects of rigid benzofurane 3, 4 dihydroxy chalcon (DHC) in mice. Annals of General Psychiatry 2010 9(Suppl 1):S124.
Submit your next manuscript to BioMed Central and take full advantage of:

- Convenient online submission

- Thorough peer review

- No space constraints or color figure charges

- Immediate publication on acceptance

- Inclusion in PubMed, CAS, Scopus and Google Scholar

- Research which is freely available for redistribution

Submit your manuscript at www.biomedcentral.com/submit
C Biomed Central 